\title{
Nitrogen uptake by size-fractionated phytoplankton in mangrove waters
}

\author{
Vivek V. Dham, Mohideen Wafar*, Anjali Menezes Heredia
}

National Institute of Oceanography, Dona Paula, Goa 403 004, India

\begin{abstract}
Seasonal changes in the uptake of nitrogenous nutrients (nitrate, nitrite, ammonium and urea) in 2 size fractions (netplankton: 20 to $200 \mu \mathrm{m}$; and nanoplankton: 0.8 to $20 \mu \mathrm{m}$ ) were studied in relationship to the phytoplankton species composition in mangrove waters on the west coast of India. Seasonal changes in particulate organic nitrogen in the nano- and netplankton fractions were similar, whereas those of chlorophyll a varied, showing high values in nanoplankton in pre-monsoon and in netplankton in monsoon and early post-monsoon months. Nitrogen uptake as the sum of all 4

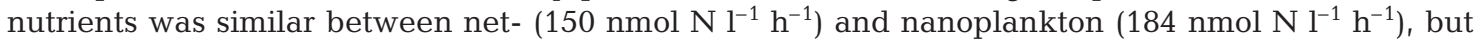
differed substantially according to the $\mathrm{N}$ compound. Netplankton were responsible for $>90 \%$ of the nitrate taken up, and nanoplankton for $>80 \%$ of the ammonium uptake. Netplankton also took up ammonium (31 nmol N l $\mathrm{N}^{-1} \mathrm{~h}^{-1}, 20 \%$ of the total $\mathrm{N}$ taken up), whereas nitrate uptake $\left(3 \mathrm{nmol} \mathrm{N} \mathrm{l}^{-1} \mathrm{~h}^{-1}\right.$ ) in the nanoplankton amounted to only about $2 \%$ of the total $\mathrm{N}$ uptake. The size-dependent differences in the utilisation of nitrate and ammonium appear to be further enhanced by a reduction in nitrate uptake through increased water temperatures and a greater repression of nitrate uptake in the nanoplankton than in the netplankton at ambient ammonium concentrations of $>0.5 \mu \mathrm{mol} \mathrm{N}^{-1}$. The proportions of nitrite and urea uptake in the 2 size classes were similar to those of nitrate and ammonium, indicating size-dependent uptake of these 2 compounds as well. Pennate diatoms and flagellates were dominant during high nitrate uptake, and centric diatoms and blue green algae during high ammonium uptake. Species succession, however, is probably related to changes in salinity.
\end{abstract}

KEY WORDS: Nitrogen uptake · Size fractions · Phytoplankton - Mangrove · Tropical waters · West coast of India

Resale or republication not permitted without written consent of the publisher

\section{INTRODUCTION}

Phytoplankton are capable of taking up and assimilating simultaneously, or in an order of preference, several forms of dissolved nitrogen compounds. In neritic and estuarine waters this is an indicator of the ecosystem's ability to cope with spatially and temporally varying loads of different forms of $\mathrm{N}$, especially as nitrate and ammonium, from fluvial and anthropogenic sources. The preference for either ammonium or nitrate has also been shown in many studies to be associated with size classes of phytoplankton (see Wilkerson et al. 2000). Hence, chronic addition of either of these compounds is likely to entail substantial changes in the composition of phytoplankton and, in turn, affect trophic dynamics (Doering et al. 1989), including, as in the case of excessive nitrate loading, the promotion of incidences of toxic algal blooms (Maguer et al. 2004).

What we know so far of the association between size classes and the type of $\mathrm{N}$ nutrient used comes essentially from studies carried out in northern temperate (Glibert et al. 1982, Furnas 1983, Harrison \& Wood 1988, Kokkinakis \& Wheeler 1988, Bode \& Dortch 1996, Dauchez et al. 1996, Riegman \& Noordeloos 1998, Riegman et al. 1998, Wilkerson et al. 2000, Wafar et al. 2004) and southern temperate (Probyn 1985, Probyn \& Painting 1985, Chang et al. 1989, 1992) coastal and estuarine waters, with none from tropical seas. In our previous study on $\mathrm{N}$ uptake in a mangrove ecosystem (Dham et al. 2002), we showed that nitrate and ammonium were taken up by phytoplankton at more or less similar quantities over the seasonal cycle, but that the patterns 
were temporally separated, with uptake of the former becoming dominant in the post-monsoon period (October to January), and of the latter in the pre-monsoon period (February to May). At that time, we also measured the uptake of $4 \mathrm{~N}$ compounds (nitrate, ammonium, nitrite and urea) in 2 size fractions (netplankton: 20 to $200 \mu \mathrm{m}$; and nanoplankton: 0.8 to $20 \mu \mathrm{m}$ ). In the present study, we report on these data and examine the relationships between phytoplankton size classes and the pattern of $\mathrm{N}$ nutrient utilisation.

\section{MATERIALS AND METHODS}

The Achara mangrove $\left(16^{\circ} 12^{\prime}\right.$ to $16^{\circ} 14^{\prime} \mathrm{N}, 73^{\circ} 25^{\prime}$ to $73^{\circ} 30^{\prime} \mathrm{E}$ ), where the present study was carried out, is the least disturbed mangrove ecosystem on the west coast of India (Fig. 1). The seasonal climatic pattern in the study area can be broken down into the monsoon (June to September-heavy rainfall), post-monsoon (October to January - dry and cool) and pre-monsoon (February to May - dry and hot) periods.

Environmental parameters, the nutrients and rates of $\mathrm{N}$ uptake and the remineralisation by unfractionated plankton were measured at 3 stations (Fig. 1) over a series of 16 samplings between February 1997 and June 1998 (with the exception of April 1997) and have been reported elsewhere (Dham et al. 2002). N uptake by size-fractionated plankton studied in 10 of these samplings forms the database of the present paper.

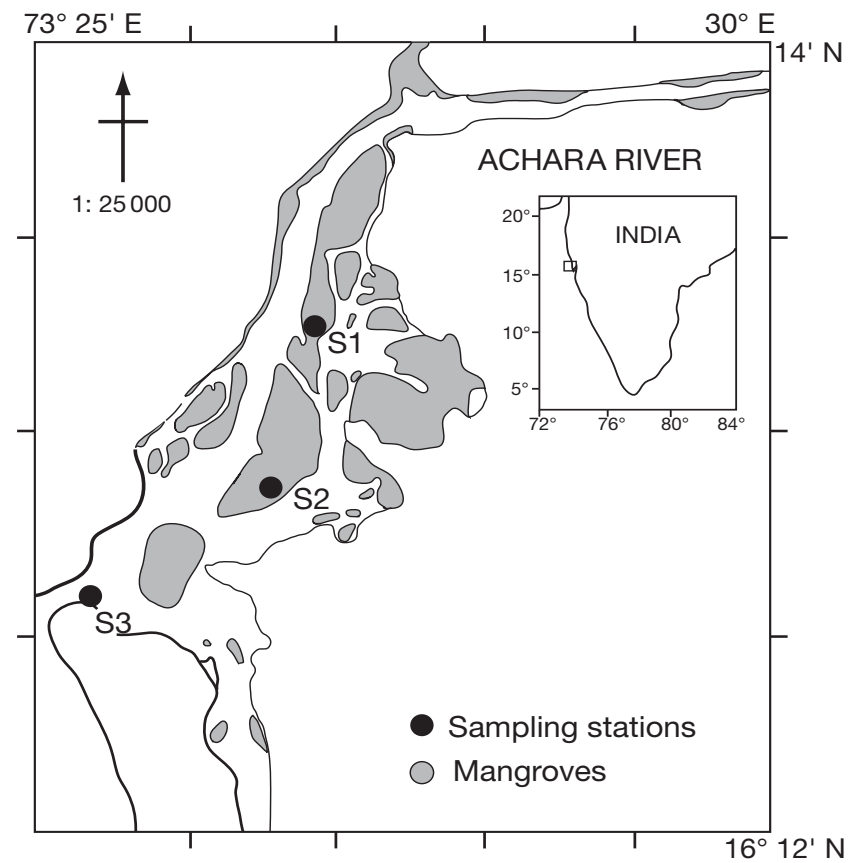

Fig. 1. Location of the Achara estuary and the sampling stations
Water samples with netplankton (20 to $200 \mu \mathrm{m}$ ) and nanoplankton $(0.8$ to $20 \mu \mathrm{m})$ sized particles were obtained by serial filtration through 200 and $20 \mu \mathrm{m}$ bolting silk and $0.8 \mu \mathrm{m}$ glass-fibre filters, and were used for measurements of chlorophyll a (chl a) and particulate organic nitrogen (PON). Particulate matter from both fractions was recovered by filtration onto pre-combusted GF/F filter pads. PON was measured by acid digestion, steam distillation of ammonium and titration with a micro-processor-controlled Metrohm Dosimat 665 unit, with an analytical precision of $\pm 0.15 \mu \mathrm{mol} N$. Chl a was measured by spectrophotometry (Strickland \& Parsons 1972). Unfiltered samples were used for phytoplankton cell counts. The samples were fixed with $1 \%$ Lugol's iodine solution, allowed to settle for $24 \mathrm{~h}$ and examined under an inverted microscope.

Samples for $\mathrm{N}$ uptake measurements were prefiltered through $200 \mu \mathrm{m}$ Nytex net and transferred to 11 glass bottles, to which $\mathrm{Na}^{15} \mathrm{NO}_{3}, \mathrm{Na}^{15} \mathrm{NO}_{2},{ }^{15} \mathrm{NH}_{4} \mathrm{Cl}$ and $\mathrm{CO}\left({ }^{15} \mathrm{NH}_{2}\right)_{2}$ (97.4 atom\% enrichment for nitrate and $95 \%$ for the other 3 nutrients; KOR isotopes) were added at concentrations $\leq 10 \%$ of the ambient levels. The bottles were placed in a large trough filled with seawater and incubated for $4 \mathrm{~h}$ under in situ conditions. The ambient temperature was maintained by frequent changes of seawater. Incident light on the incubation bottles was measured at hourly intervals during the incubation period using a LiCor photometer. Size fractionation was done post-incubation in order to avoid unrealistic uptake rates, especially in the smaller fraction (Dauchez et al. 1996). All the filtrations, including those for recovery of particulate matter for chl $a$ and PON measurements, were done under low vacuum (<200 $\mathrm{mm} \mathrm{Hg})$.

${ }^{15} \mathrm{~N}:{ }^{14} \mathrm{~N}$ isotope ratios of the particulate matter were measured by emission spectrometry using a Jasco N150 nitrogen analyser. As the PON was measured in a sample different from that incubated with ${ }^{15} \mathrm{~N}$, the absolute uptake rate reported here is a product of the specific uptake rate and the initial PON concentration. Specific and absolute uptake rates were calculated following the equation of Dugdale \& Goering (1967). Model II regressions were used in evaluating all linear relationships between variables.

\section{RESULTS}

\section{Salinity, temperature and nutrients}

Seasonal changes in hydrographic parameters and nutrient concentrations have been reported in Dham et al. (2002). In brief, the study area remains freshwater-dominated during monsoons and becomes pro- 
gressively seawater-dominated through post- and premonsoon months. Nitrogenous nutrients remain available at measurable concentrations throughout the year, with high concentrations of nitrate and nitrite in monsoon and post-monsoon months and of ammonium and urea in pre-monsoon months.

\section{PON and chl a}

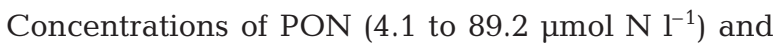
chl a (0.2 to $\left.17.4 \mathrm{\mu g} \mathrm{l}^{-1}\right)$ in nanoplankton were generally greater than in netplankton (5.5 to $71.7 \mu \mathrm{mol} \mathrm{N} \mathrm{^{-1 }}$ and 0.2 to $12.3 \mu \mathrm{g} \mathrm{l}^{-1}$, respectively), except from September to December (Fig. 2). The differences between annual averages, however, were not large, with a nano- to netplankton ratio of 1.16 for PON and of 1.1 for chl a. When the monsoon values were excluded, the relationship between PON and chl $a$ in the netplankton fraction was significant, with a PON:chl a ratio of $3.29 \mu \mathrm{mol} \mathrm{ug}^{-1} \mathrm{chl} \mathrm{a}(95 \% \mathrm{CI}: 1.32$ and 5.22, $\mathrm{r}=0.71, \mathrm{n}=21, \mathrm{p}<0.01)$ and a detrital component of

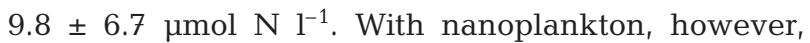
there was no statistically significant relationship between PON and chl a.

\section{$\mathrm{N}$ uptake rates}

The total $\mathrm{N}$ (sum of nitrate, ammonium, urea and nitrite) uptake by netplankton was generally greater than that measured in the nanoplankton fraction for most of the time at all stations, with the latter exceeding the former only in the pre-monsoon season of the annual cycle (Fig. 3). Except during the unusually high $\mathrm{N}$ uptake in May in the nanoplankton fraction, netplankton accounted for 56,66 and $76 \%$ of the total $\mathrm{N}$ uptake at Stns 1, 2 and 3, respectively. Seasonally, high $\mathrm{N}$ uptake in the netplankton immediately followed the monsoon period, with a progressive decrease thereafter. This seasonality was more pronounced at Stns 1 and 2. Except for the pre-monsoon high, $\mathrm{N}$ uptake by nanoplankton did not show any strong seasonal variation.
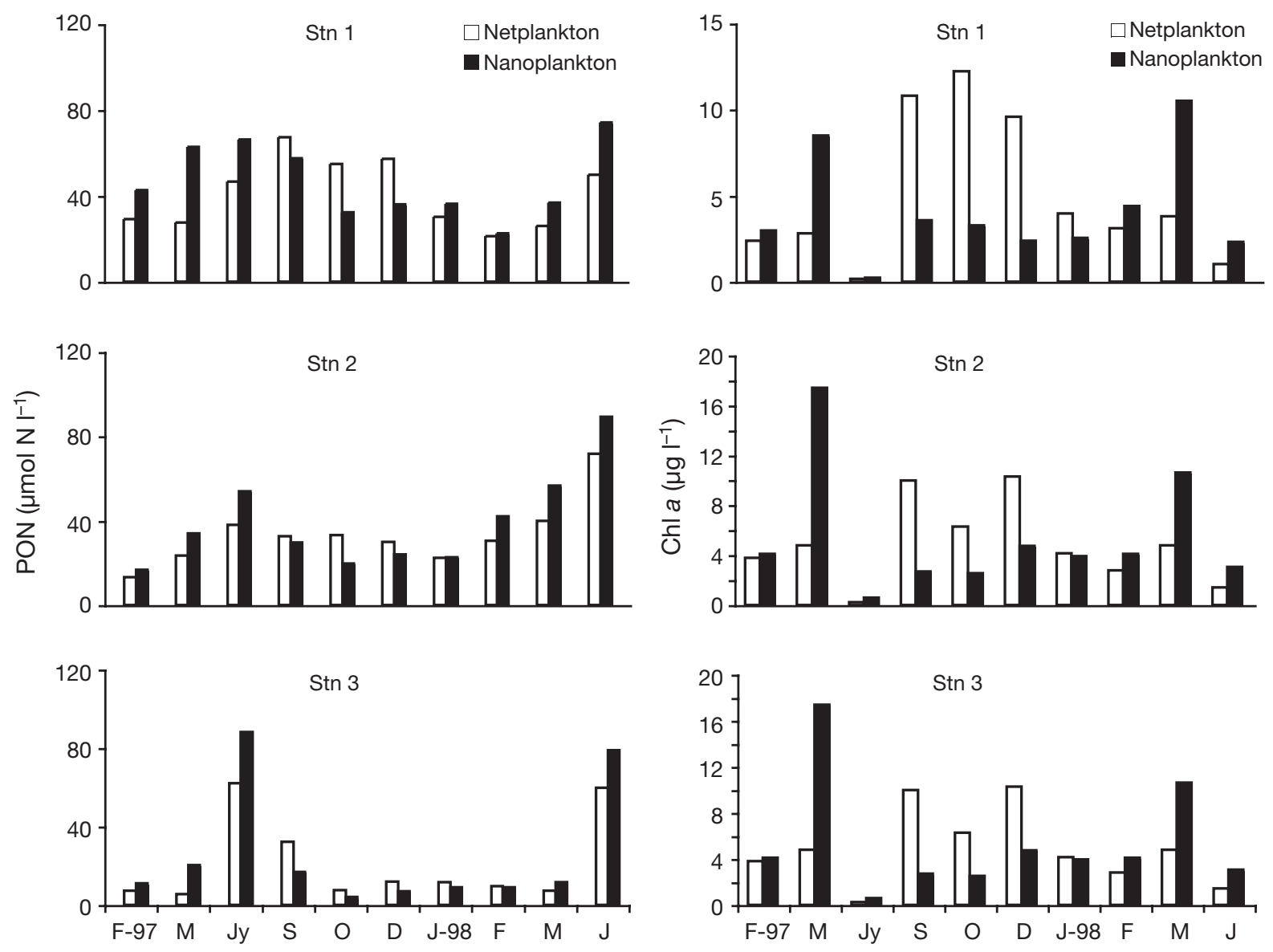

Fig. 2. Seasonal changes in particulate organic nitrogen (PON) and chlorophyll a (chl a) of net- and nanoplankton at the 3 stations 

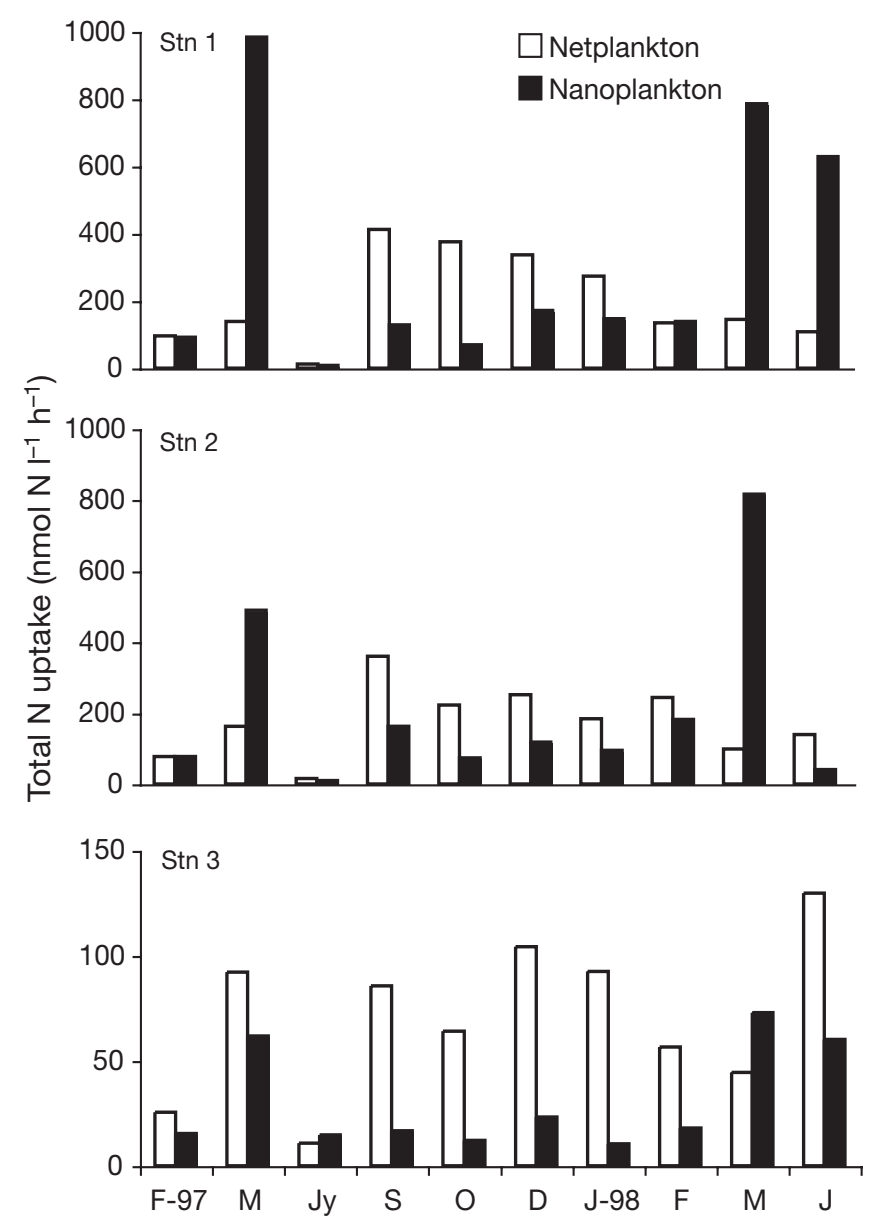

Fig. 3. Seasonal changes in total $\mathrm{N}$ uptake by net- and nanoplankton at the 3 stations

\section{$\mathbf{N}$ uptake in netplankton}

Annual averages showed that nitrate was the major form of $\mathrm{N}$ utilised by the netplankton $\left(99.5 \mathrm{nmol} \mathrm{N} \mathrm{^{-1 }}\right.$ $\mathrm{h}^{-1}$ ), followed by ammonium (30.7 nmol $\left.\mathrm{N} \mathrm{l}^{-1} \mathrm{~h}^{-1}\right)$,

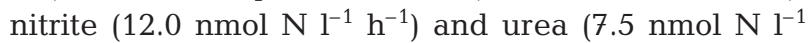
$\mathrm{h}^{-1}$ ) (Fig. $4 \mathrm{a}-\mathrm{c}$ ). Starting with the monsoon, nitrate was the major $\mathrm{N}$ source (range: 63 to $95 \%$; average: $81.8 \%$ ) for netplankton; this situation continued into the pre-monsoon months. Ammonium, relatively inappreciable (range: 2 to $22 \%$; average: $9 \%$ ) during the post-monsoon months, became an important $\mathrm{N}$ source in the pre-monsoon period (range: 5 to $75 \%$; average: $33.2 \%)$, but still was not as significant as nitrate. Seasonal patterns of nitrite and urea utilisation were, however, less marked. In the case of nitrite, peak uptake occurred in September at Stns 1 and 3 and in October to December and May at Stn 2. Uptake rates of all the 4 nutrients by netplankton were substantially higher at the stations dominated by mangroves (Stns 1 and 2), translating into statistically significant differences between uptake rates at these stations and those at $\operatorname{Stn} 3\left(F_{1,28} \mathrm{\rho NO}_{3}{ }^{-}=3.2, \mathrm{p}<0.05_{;} F_{1,28}\right.$ $\rho \mathrm{NO}_{2}{ }^{-}=7.1, \mathrm{p}<0.05 ; F_{1,28} \mathrm{\rho NH}_{4}{ }^{+}=12, \mathrm{p}<0.05 ; F_{1,28}$ purea $=6.9, \mathrm{p}<0.05$ ).

The uptake of ammonium was related to substrate concentrations throughout the year $(\mathrm{r}=0.58, \mathrm{n}=25$, $\mathrm{p}<0.01$ ). In contrast, nitrate uptake was related to substrate only during the dry season $(\mathrm{r}=0.59, \mathrm{n}=18, \mathrm{p}<$ 0.01). Relationships between $\mathrm{N}$ uptake and chl $a$ were significant in the case of nitrate, but with different slopes between the first 2 stations (assimilation ratio of $21.8 \mathrm{nmol} \mathrm{N} \mathrm{ug}^{-1} \mathrm{chl} \mathrm{a} \mathrm{h}^{-1}$ [95\% CI: 12.3 and $29.7 \mathrm{nmol}$ $\mathrm{N} \mathrm{ug}^{-1} \mathrm{chl} \mathrm{a} \mathrm{h}^{-1}$ ]; $\left.\mathrm{r}=0.85, \mathrm{n}=20, \mathrm{p}<0.01\right]$ and Stn 3 (5.8 nmol N $\mu^{-1} \mathrm{chl} \mathrm{a} \mathrm{h}^{-1}$ [95\% CI: 1 and $10.4 \mathrm{nmol} \mathrm{N}$ $\mu \mathrm{g}^{-1} \mathrm{chl} \mathrm{a} \mathrm{h}^{-1}$ ]; $\mathrm{r}=0.79, \mathrm{n}=9, \mathrm{p}<0.01$ ). The same was the case with nitrite at Stns 1 and 2 (assimilation ratio of 2.9 [95\% CI: 0.8 and 4.9] nmol N $\mathrm{ng}^{-1} \mathrm{chl} a \mathrm{~h}^{-1} ; \mathrm{r}=$ $0.68, \mathrm{n}=20, \mathrm{p}<0.01$ ). No statistically valid relationships between $\mathrm{N}$ uptake and chl a were detected in the cases of ammonium and urea.

\section{$\mathbf{N}$ uptake in nanoplankton}

Ammonium was the major form of $\mathrm{N}$ utilised by nanoplankton at all times of the year, with an annual average uptake of $163.4 \mathrm{nmol} \mathrm{N} \mathrm{l}^{-1} \mathrm{~h}^{-1}$, which was $\geq 1$ order of magnitude higher than that of urea

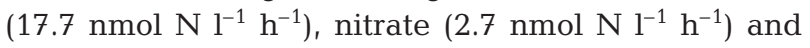

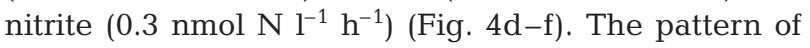
ammonium uptake was also strongly seasonal; uptake in the pre-monsoon months (range: 7.4 to $932 \mathrm{nmol} \mathrm{N}$ $\mathrm{l}^{-1} \mathrm{~h}^{-1}$; average: $291.4 \mathrm{nmol} \mathrm{N} \mathrm{l}^{-1} \mathrm{~h}^{-1}$ ) was 2-fold higher, including a distinct peak in May, than in the

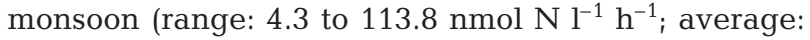

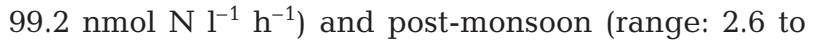
134.6 nmol $\mathrm{N} \mathrm{l}^{-1} \mathrm{~h}^{-1}$; average: $57.1 \mathrm{nmol} \mathrm{N} \mathrm{l}^{-1} \mathrm{~h}^{-1}$ ) months. Though the seasonal pattern of urea uptake was not well marked, peak uptake rates were still seen in May at Stns 1 and 2 and in June at Stn 3. Nitrate and nitrite uptake rates, though relatively unimportant, also showed distinct seasonal variations, with 2 to 3 times higher rates in the post-monsoon

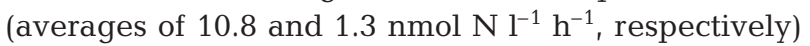
than in the pre-monsoon (averages of 3.5 and

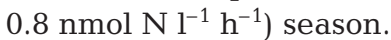

Among the 4 nutrients, only seasonal changes in the uptake of ammonium were related to substrate concentrations ( $\mathrm{r}=0.75, \mathrm{n}=30, \mathrm{p}<0.01)$ and to $\mathrm{chl} a$, with an average assimilation ratio of $48 \mathrm{nmol} \mathrm{N} \mathrm{Ng}^{-1} \mathrm{chl} \mathrm{a}$ $\mathrm{h}^{-1}\left(95 \% \mathrm{CI}: 11\right.$ and $88 \mathrm{nmol} \mathrm{N} \mathrm{gg}^{-1} \mathrm{chl} \mathrm{a} \mathrm{h}^{-1} ; \mathrm{r}=0.67$, $\mathrm{n}=20, \mathrm{p}<0.01$ ) at Stns 1 and 2. This assimilation ratio was an order of magnitude higher than that $4.5 \mathrm{nmol}$

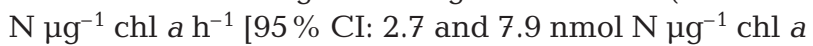
$\left.\left.\mathrm{h}^{-1} ; \mathrm{r}=0.77, \mathrm{n}=10, \mathrm{p}<0.01\right]\right)$ found at $\operatorname{Stn} 3$. 

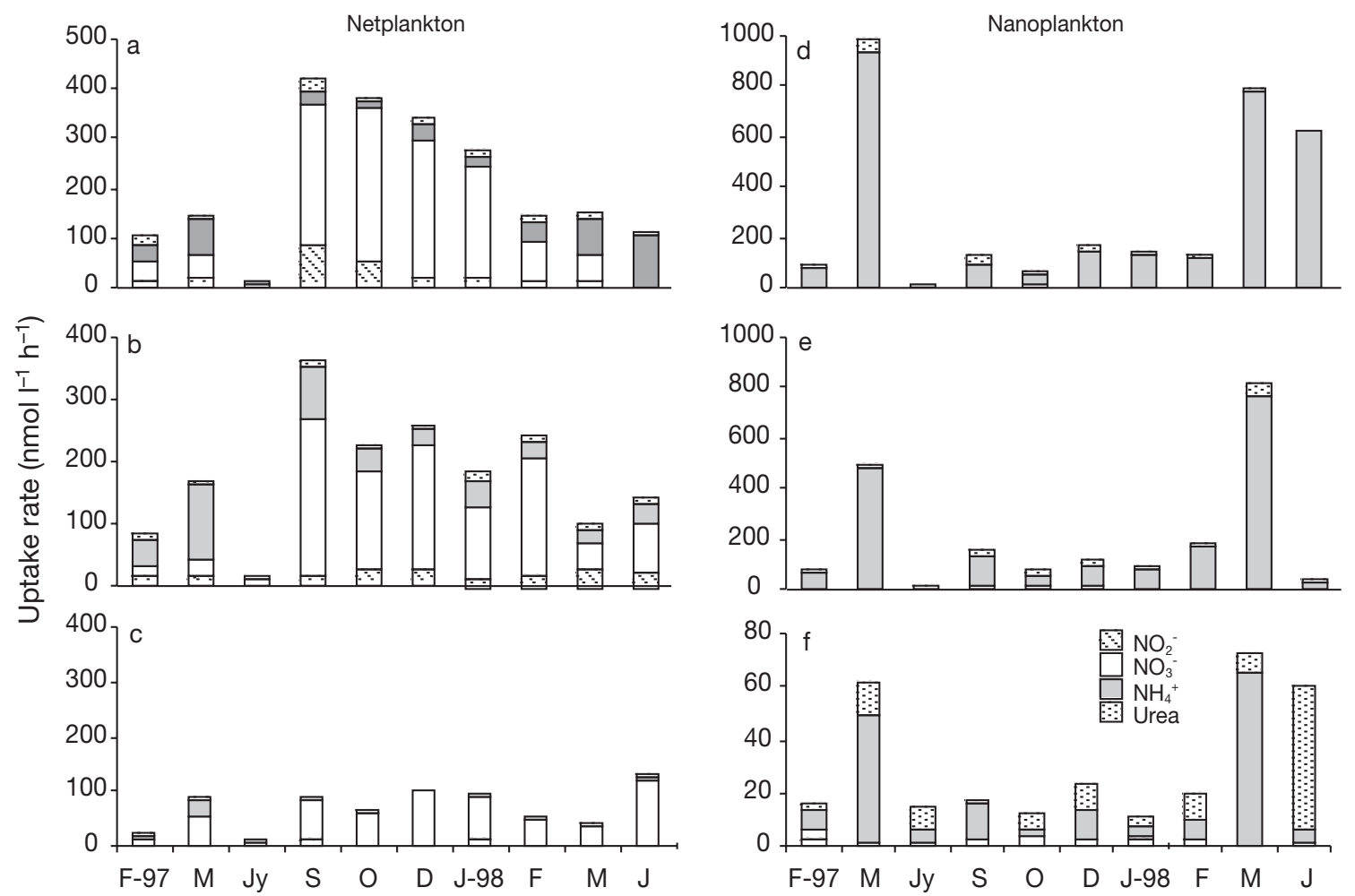

Fig. 4. Seasonal changes in uptake of $N$ nutrients by net- and nanoplankton at Stns (a,d) 1, (b,e) 2 and (c,f) 3

\section{Phytoplankton groups}

Except for the month of May, diatoms were the major component at all times, accounting, on average, for $>60 \%$ of the cell counts (Fig. $5 \mathrm{a}-\mathrm{C}$ ). Next in order of importance were flagellates and blue green algae, but with dominance in different months - the former were abundant in post-monsoon months (up to $30 \%$ of total counts in some months), and the latter in pre-monsoon months, especially in May when their proportion in cell counts was between 70 and $80 \%$. The coccolithophorids were few in numbers at all times, and their contribution was rarely $>1 \%$ of the total counts. Among the diatoms, centric forms were dominant during pre-monsoon months (accounting for $61 \%$ ) and the pennates in post-monsoon months, with an average contribution of up to $76 \%$ of the diatom counts.

A major point of interest in the relationship between changes in the relative abundance of different algal groups and the type of nutrient taken up is the affinity of an algal group to one nutrient or another. At all 3 stations, changes in the percentage abundance of pennate diatoms and flagellates followed a trend remarkably similar to that of nitrate uptake (Fig. 6a-b). Likewise, the percentages of centric forms in the total diatom counts and those of blue green algae in total counts changed in a manner similar to those of ammo- nium uptake (Fig. 6c-d). It is also of interest to note that the Trichodesmium blooms coincided with the pre-monsoon ammonium uptake peaks: though atmospheric nitrogen fixers, Trichodesmium are also capable of assimilating combinations of dissolved inorganic N species (Stal \& Walsby 1998, Mulholland et al. 1999).

\section{DISCUSSION}

Since the hypothesis of Malone (1980), associating larger phytoplankton cells with nitrate-rich waters and smaller cells with oligotrophic waters, quite a number of studies on the type of $\mathrm{N}$ nutrients (nitrate or ammonium) taken up by size-fractionated phytoplankton assemblages on spatial (Probyn 1985, Kokkinakis \& Wheeler 1988, Chang et al. 1989, Bode \& Dortch 1996) and temporal (Glibert et al. 1982, Furnas 1983, Chang et al. 1992, Riegman \& Noordeloos 1998, Riegman et al. 1998) scales have lent support to this. The patterns of $N$ nutrition demonstrated in these studies are more or less similar: larger cells account for a larger proportion of total $\mathrm{N}$ taken up in nitrate-rich nearshore waters, with a decrease in their importance towards offshore; larger cells almost universally tend to assimilate more nitrate than ammonium; smaller cells prefer ammonium over nitrate as an $\mathrm{N}$ source; $>50$ to almost $100 \%$ of the 

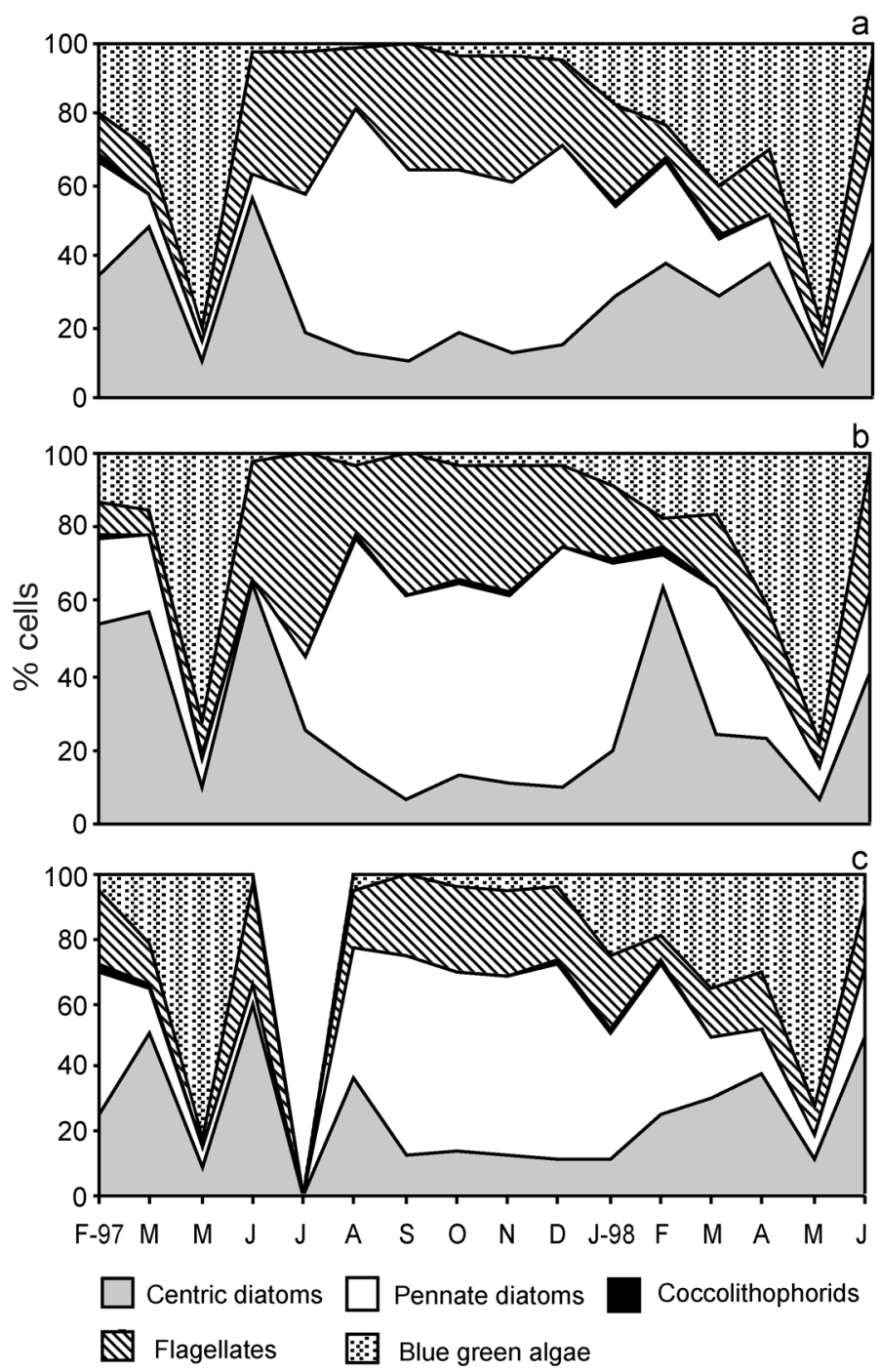

Fig. 5. Seasonal changes in proportions of phytoplankton groups at Stns (a) 1, (b) 2 and (c) 3. Note absence of data for July 1997 at Stn 3

ammonium assimilated could become localised in the nanoplankton fraction; and the relative abundance of nitrate or ammonium, respectively, in winter/spring or summer in temperate seas, determines the succession of net- and nanoplankton populations. The differences in the abundance of autotrophic size classes have, at times, been explained to be a function of hydrodynamics (Legendre \& LéFevre 1991), selective grazing (Riegman et al. 1993), or the result of diffusion-limited acquisition of ammonium (Pasciak \& Gavis 1974), which would necessitate the larger cells to be more dependent on alternative $\mathrm{N}$ sources, especially on nitrate when it is available at high concentrations (Stolte et al. 1994).

Departures from this pattern are not uncommon, however. Dauchez et al. (1996) found in Scotia Shelf waters that the large and small phytoplankton tended to have the same uptake behaviour with respect to nitrate and that there was no visible succession of the phytoplankton distribution in relation with nutrients. According to Chisholm (1992), the dominance of larger cells in areas enriched with nitrate does not appear to be the result of a link between cell size and preference for either nitrate or ammonium.

Nitrate-ammonium interactions in phytoplankton $\mathrm{N}$ nutrition could also be more complex than a simple relation between cell size and type of $\mathrm{N}$ nutrient used. Repression of nitrate uptake by high concentrations of ammonium has been shown in natural unsorted populations (Dortch 1990) and with a size-independent cell in mathematical models (Flynn et al. 1997); such repression could weaken in the presence of high concentrations of nitrate and low temperature (Flynn 1999). A recent study of size-fractionated uptake of nitrate and ammonium in the coastal waters of Brittany (Wafar et al. 2004) showed that the observed patterns of $\mathrm{N}$ nutrition could be explained by changes in the proportion of nitrate and ammonium in the ambient $\mathrm{N}$ and size: the pattern of $\mathrm{N}$ nutrition was size-independent when concentrations of nitrate were high, those of ammonium low, and temperature low and became ammonium-, and to some extent size-, dependent when the opposite conditions prevailed.

Several observations and relational changes in our study suggest size-dependent utilisation of nitrate and ammonium as an $\mathrm{N}$ source. Firstly, changes in the concentrations of chl a related significantly to nitrate uptake in netplankton and ammonium uptake in nanoplankton, but not to the 3 other nutrients. Secondly, assimilation ratios of nitrate were consistently greater than those of ammonium in netplankton, while the reverse was the case for nanoplankton (Table 1). Thirdly, all ratios of nitrate uptake between net- and nanoplankton were $>3$, and those of ammonium uptake were $<1$, with most of them $<0.6$. Lastly, ratios of nitrate-to-ammonium uptake in netplankton were $>1$, except in 3 instances, whereas all such ratios in nanoplankton were $<1$.

Our data also suggest that the observed patterns of $\mathrm{N}$ nutrition could be explained by interaction between nitrate and ammonium. The model of Flynn et al. (1997) suggests that in a 'non-size-differentiated' cell,

Table 1. Chl-normalised nitrate and ammonium uptake rates (nmol N $\mathrm{ug}^{-1} \mathrm{Chl} \mathrm{a} \mathrm{h}^{-1}$ ) in net- and nanoplankton fractions in the Achara estuary

\begin{tabular}{|c|c|c|c|c|}
\hline \multirow[t]{2}{*}{ Stn } & \multicolumn{2}{|c|}{ Netplankton } & \multicolumn{2}{|c|}{ Nanoplankton } \\
\hline & Nitrate & Ammonium & Nitrate & Ammonium \\
\hline 1 & $1.4-55.4$ & $1-105$ & $0-4.21$ & $9.8-270$ \\
\hline 2 & $4.4-67.5$ & $2.9-25.5$ & $0.03-4.6$ & $7.2-71.9$ \\
\hline 3 & $3.5-74.2$ & $0.14-16$ & $0.01-1.5$ & $0.87-14.8$ \\
\hline
\end{tabular}



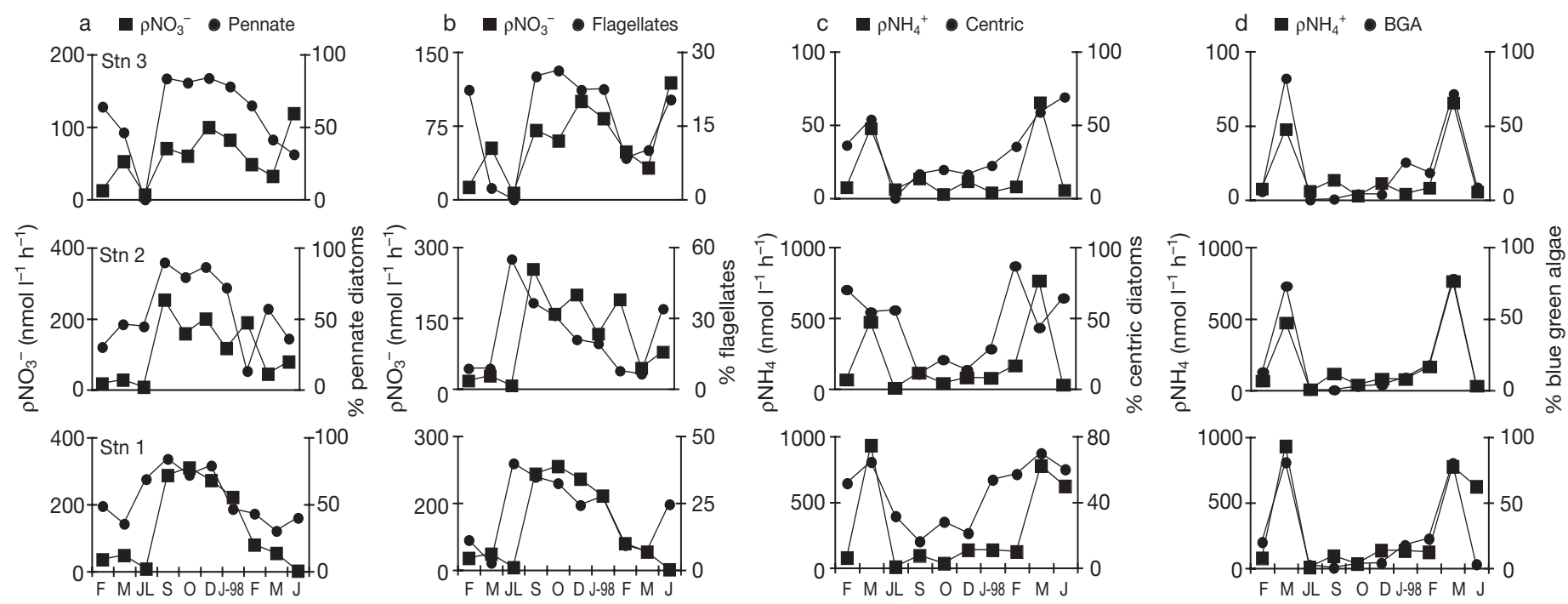

Fig. 6. Relationships between nitrate or ammonium uptake and phytoplankton species abundance. Nitrate uptake by netplankton and percentage of (a) pennate diatoms and (b) flagellates in cell counts. Ammonium uptake by nanoplankton and percentage of

(c) centric diatoms and (d) blue green algae (BGA) in cell counts

uptake of nitrate gets repressed when ambient ammonium concentrations increase. Evidence for the repression of nitrate uptake by ammonium can be seen when ratios of nitrate-to-ammonium uptake rates in net- and nanoplankton are plotted as a function of ambient ammonium concentrations (Fig. 7). In both cases, the pattern of changes followed first-order kinetics, with slopes of $\mathrm{e}^{-2.7}$ and $\mathrm{e}^{-6.2}$, respectively. Analysis of covariance showed that the 2 slopes were statistically different from each other $\left(F_{1,51} 10.9 ; \mathrm{p}<0.01\right)$, confirming that the degree of repression is more pronounced in nano- than in netplankton. The fact that such repression does indeed occur is also supported by the observation that when ammonium concentrations were $>0.5 \mu \mathrm{mol} \mathrm{N} \mathrm{^{-1 }}$ (the threshold in Fig. 7), nitrate concentrations were in the range from 0.8 to $19.6 \mu \mathrm{mol}$ $\mathrm{N}^{-1}$ and the nitrate-to-ammonium ratios were between 0.8 and 26.8 .

Patterns of nitrate and ammonium uptake are also related to water temperature, with the diatoms in cool, nitrate-enriched environments accounting for a disproportionately large fraction of total nitrate uptake. In a recent study, Lomas \& Glibert (1999) showed, through controlled experiments, a clear relationship between temperature changes and nitrate and ammonium uptake, with a statistically significant
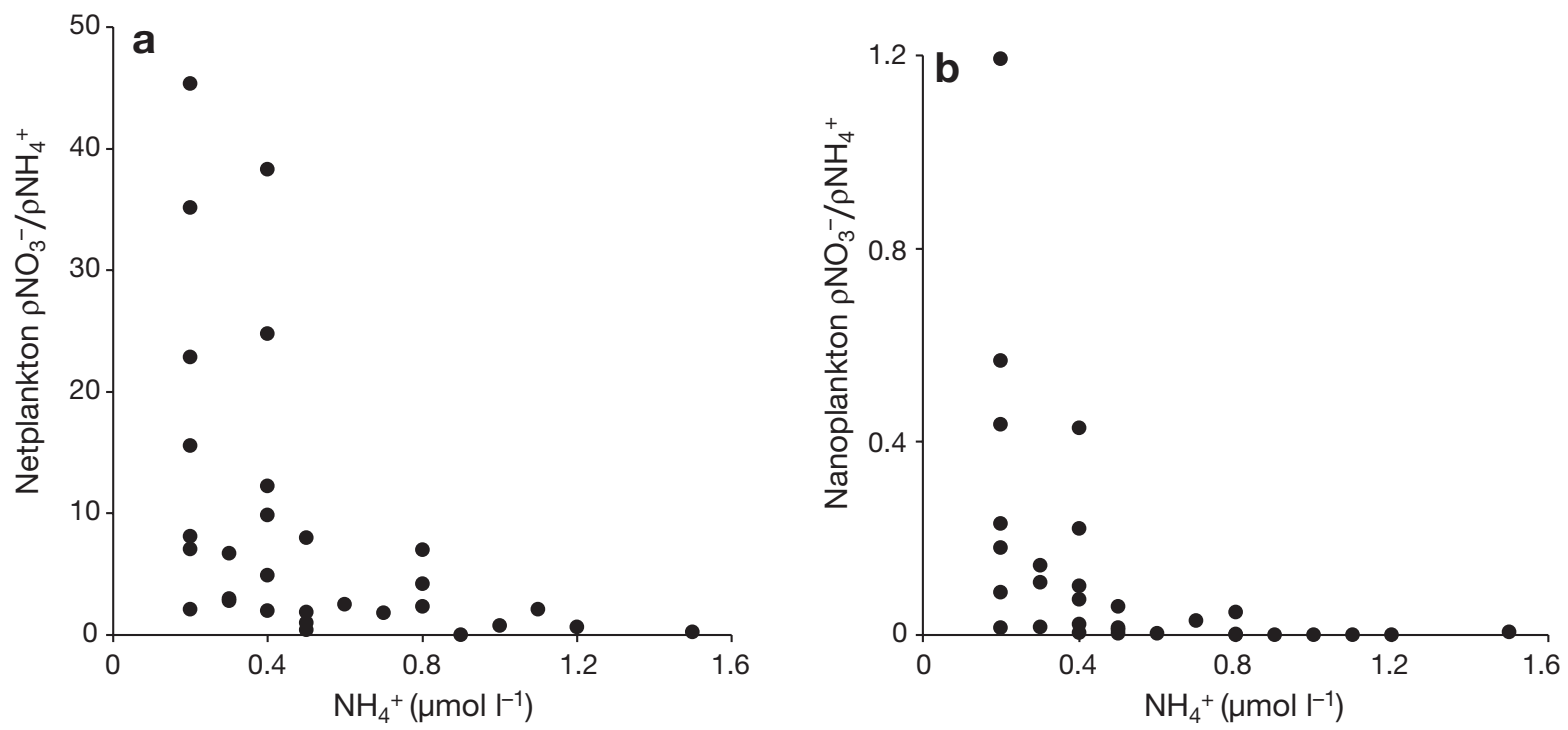

Fig. 7. Changes in the ratios of nitrate:ammonium uptake in (a) net- and (b) nanoplankton as a function of ammonium concentrations 
reduction of the former, ranging from 3.6 to $23 \mathrm{nmol} \mathrm{N}$ $\left(\mathrm{h}{ }^{\circ} \mathrm{C}\right)^{-1}$, and an increase in the latter, between 4 and $5.9 \mathrm{nmol} \mathrm{N}\left(\mathrm{h}{ }^{\circ} \mathrm{C}\right)^{-1}$, over the range of temperatures tested. Examination of our data from this perspective showed such relations. The negative relationship between changes of chl-normalised nitrate uptake and temperature in netplankton at Stns 1 and 2 was significant, with a slope of $-4.4 \mathrm{nmol} \mathrm{N}$ ( $\mu \mathrm{g}$ chl a $\left.\mathrm{h}{ }^{\circ} \mathrm{C}\right)^{-1}(\mathrm{r}=0.72, \mathrm{n}=17$ ) (Fig. 8a). In a similar way, changes of chl-normalised ammonium uptake in nanoplankton at these stations related positively to those of temperature, with a slope of $3.2 \mathrm{nmol} \mathrm{N}$ ( $\left.\mu \mathrm{g} \mathrm{chl} \mathrm{a} \mathrm{h}{ }^{\circ} \mathrm{C}\right)^{-1}(\mathrm{r}=0.49, \mathrm{n}=19)$ (Fig. 8b). No such significant relationships could be seen at Stn 3, probably because of low uptake rates.
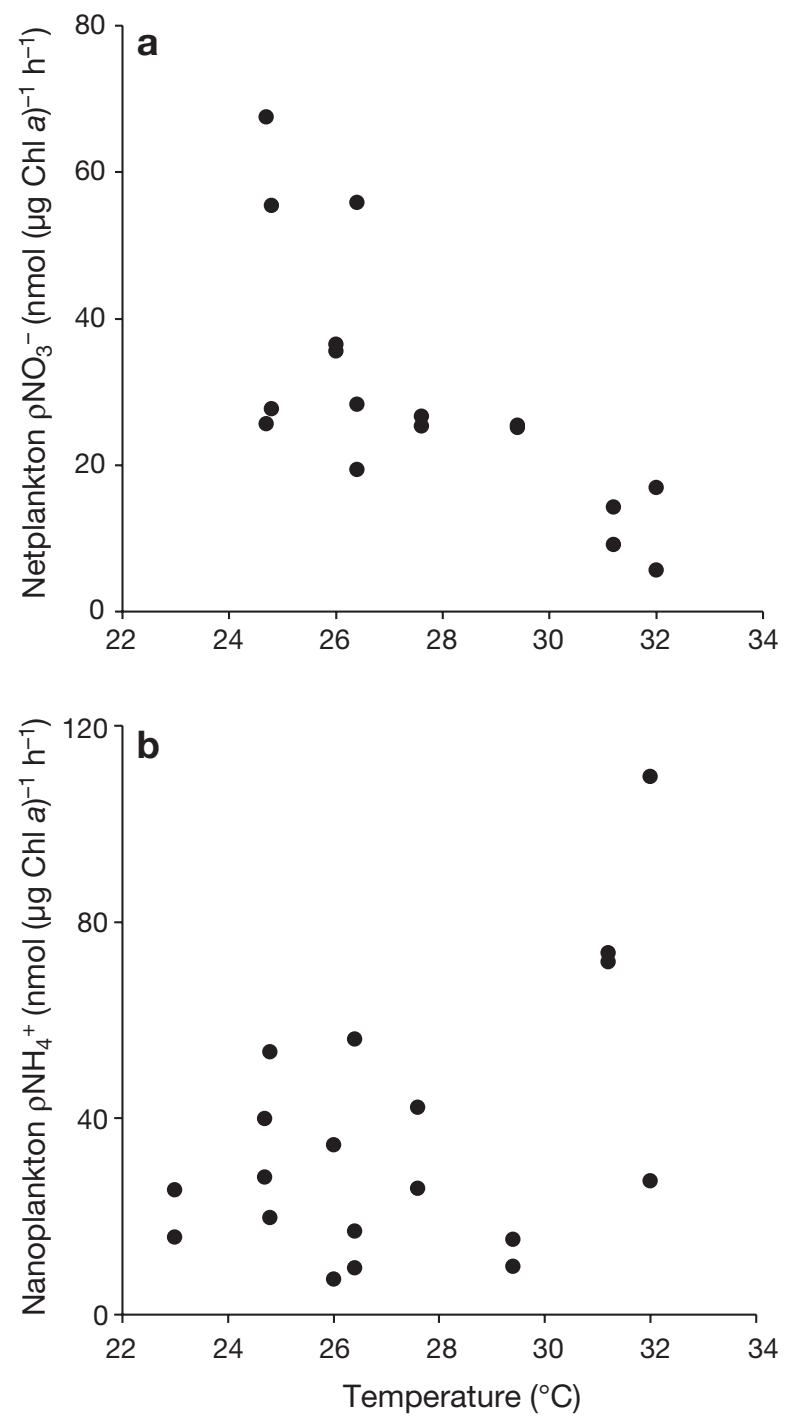

Fig. 8. Chl-normalised nitrate uptake in (a) netplankton and (b) ammonium uptake in nanoplankton as a function of water temperature
Interpretation of the changes in nitrate uptake from field data solely as a function of temperature could be a problem because of the changes in other variables like substrate concentrations, biomass and light. The general trend of the relationship between temperature and nitrate in marine waters is a negative one, so that at high temperatures a lack of substrate could lead to a reduction in nitrate uptake. This was, however, not the case here, as shown by the positive relationship between temperature and nitrate concentrations (Fig. 9), a situation that might be due to an increase in nitrification rates with temperature (Dham et al. 2002). Unlike in the study of Lomas \& Glibert (1999), by using chlnormalised nitrate uptake rates, we also minimised the effects of variations in biomass. In spite of the narrow temperature range and possible influences of light and phytoplankton species composition on nitrate uptake, the relationship obtained is significant and, hence, in support of the findings of Lomas \& Glibert (1999). Of special interest is the ratio we obtained $(-4.4 \mathrm{nmol} \mathrm{N}$ $\left[\mu \mathrm{g} \mathrm{chl} \mathrm{a} \mathrm{h}{ }^{\circ} \mathrm{C}\right]^{-1}$ ), which is much higher than those (ca. -0.53 to $2.3 \mathrm{nmol} \mathrm{N}$ [ $\left.\mu \mathrm{g} \operatorname{chl~a~h~}{ }^{\circ} \mathrm{C}\right]^{-1}$ ) obtained by Lomas \& Glibert (1999) for lower temperatures, suggesting a rapid decrease in nitrate uptake through higher temperatures. This, along with the absence of a relation between ammonium uptake and temperature in netplankton, the increase of ammonium uptakebut not of nitrate uptake-with temperature in nanoplankton and the difference in the degree of repression of nitrate uptake by ammonium between net- and nanoplankton all confirm that the extent to which these variables could regulate $\mathrm{N}$ nutrition themselves is size dependent. Further support for this conclusion is found in the data of Wafar et al. (2004) on

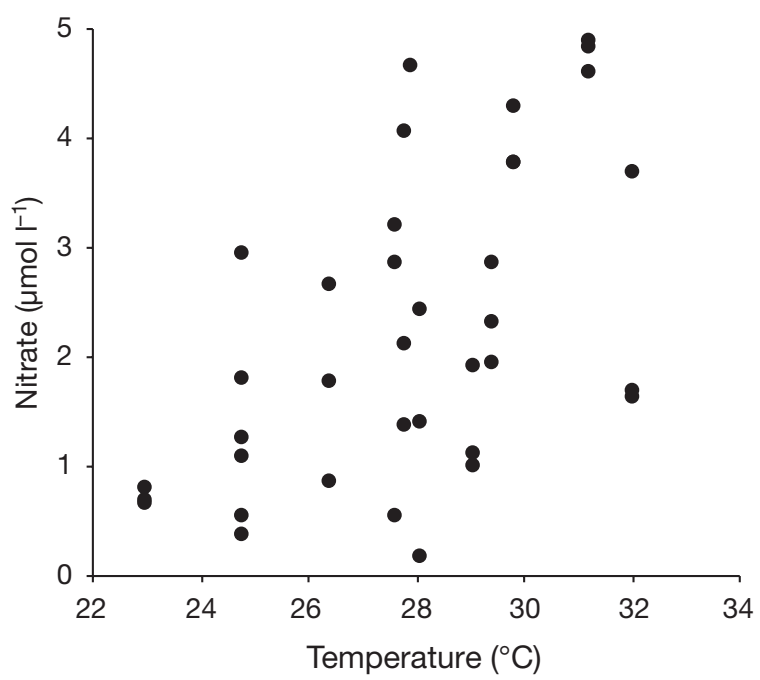

Fig. 9. Relationship between nitrate concentrations and water temperature 
size-fractionated $\mathrm{N}$ uptake in temperate coastal waters. The rate of change they determined for chlnormalised nitrate uptake in relation to temperature in netplankton (-4.9 $\mathrm{nmol} \mathrm{N}\left[\mu \mathrm{g} \mathrm{chl} \mathrm{a} \mathrm{h}{ }^{\circ} \mathrm{C}\right]^{-1}$ ) was similar to ours, but 2 to 10 times higher than in nanoplankton in their study. The data of Wafar et al. (2004) for nitrate uptake also shows that the slope at temperatures $\left.>13^{\circ} \mathrm{C}\left(-2.0 \mathrm{nmol} \mathrm{N} \text { [ } \mathrm{gg} \mathrm{chl} \mathrm{a} \mathrm{h}^{\circ} \mathrm{C}\right]^{-1}\right)$ was greater than that at lower temperatures $(-0.42 \mathrm{nmol} \mathrm{N}$ [ $\mu \mathrm{g} \operatorname{chl} \mathrm{a} \mathrm{h}$ $\left.{ }^{\circ} \mathrm{C}\right]^{-1}$ ). It was at this time that ammonium concentrations were at seasonal maxima and the associated repression of nitrate uptake appeared to be more pronounced than in netplankton, where the data were uniformly linear. The associations of nitrate uptake with netplankton and ammonium uptake with nanoplankton are thus more than simple relations altered in strength only by the range in water temperature and the extent of repression of nitrate uptake by ammonium.

Measurements of urea uptake by size fractions have been carried out less frequently (Furnas 1983, Probyn 1985, Kokkinakis \& Wheeler 1988, Chang et al. 1989, 1992, Riegman et al. 1998), and measurements of nitrite even less frequently (Wafar et al. 2004). Most of these were spatially and temporally discrete, yet showed that urea uptake, while relatively less important, was more associated with the nanoplankton fraction. In the only other comprehensive seasonal study (Wafar et al. 2004), uptake rates of urea as annual averages at 2 stations were 2 -fold higher in nanoplankton than in netplankton, while those of nitrite were not very different between these 2 fractions, but both had seasonal patterns of uptake rates similar to those of ammonium and nitrate, respectively. Our results are similar: uptake of urea as a percent of the total $\mathrm{N}$ uptake in nanoplankton ( $23 \%$ ) was 4 times higher than in netplankton $(6 \%)$, whereas that of nitrite was an order of magnitude greater in netplankton than in nanoplankton ( 7 and $0.8 \%$, respectively). These results, as well as the remarkably similar pattern of changes of nitrate and nitrite uptake in netplankton and ammonium and urea in nanoplankton (Fig. 4), confirm that the uptake of these $2 \mathrm{~N}$ nutrients is also size dependent.

Separation, using an average $\mathrm{N}$ uptake:chl a ratio of $19 \mathrm{nmol} \mathrm{N}^{-1} \mathrm{chl} a$, of $\mathrm{N}$ uptake by unfractionated populations into auto- and heterotrophic components (Dham et al. 2002) showed that the latter is an important fraction and could reach up to $50 \%$ of the total N uptake. Similar calculations made with average N uptake:chl a ratios of the 2 fractions (19.6 and

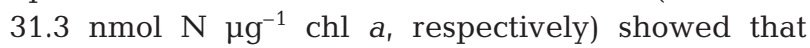
heterotrophs could account for $47 \%$ (range: 17 to $79 \%$ ) and $30 \%$ (range: 19 to $37 \%$ ) of the uptake in the netand nanoplankton fractions. While this, along with
PON:chl a ratios (Wheeler \& Kokkinakis 1990), confirms the heterotrophic status of the ecosystem, the higher percentage, along with higher PON content, in the netplankton fraction is indicative of the importance of particle-bound bacteria in the heterotrophic uptake of N. It is of interest to note that such a difference, with 2 to 4 times higher heterotrophic activity in the net- (32 and $13 \%$ ) than in the nanoplankton (8 and $7 \%$ ) fraction, even when total $\mathrm{N}$ uptake rates were comparable, has also been observed recently at 2 stations in Morlaix Bay (Wafar et al. 2004). We have not measured bacterial biomass on size-fractionated particles, but, taken in the context of the findings of Ferguson \& Rublee (1976) that $40 \%$ of the bacterial biomass in the coastal waters of North Carolina was 'attached' to particles of 6 to $50 \mu \mathrm{m}$, the greater heterotrophic activity in the netplankton fraction is understandable.

The observed changes in phytoplankton groups were different from our expectations in 2 respects. Firstly, in contrast to the observations of Berg et al. (2003), flagellates were more abundant in post-monsoon months, when more nitrate was taken up. Secondly, pennate diatoms, which are relatively small, were more abundant in the post-monsoon period, whereas centric diatoms, which are relatively large, were dominant in pre-monsoon months. In the case of flagellates, they could have been assimilating ammonium in the post-monsoon period, since ammonium uptake was still $1 / 3$ of the nitrate uptake when both fractions were taken together. They also may utilise nitrate, since proliferation of flagellates is often a result of nitrate loading (Maguer et al. 2004). In the case of diatoms, while association of the abundance of pennates (though smaller) with nitrate uptake is easy to understand, it is unclear why centric forms become dominant when nitrate uptake is lower (the abundance of diatoms as a group in pre-monsoon months is, however, lower; Fig. 5). Pre-filtration of samples may have introduced some artefacts to the $\mathrm{N}$ uptake data. For example, Rhizosolenia setigera, which is larger than $200 \mu \mathrm{m}$, was dominant in February 1997, but this species may have been eliminated when samples were pre-filtered, thus explaining why nitrate uptake was low in February. It is not easy to relate the clear-cut succession of species (Fig. 10) to either the type of $\mathrm{N}$ nutrient utilised or its proportion in the pool of total available N. For example, nitrate was still more abundant as an $\mathrm{N}$ source in pre-monsoon months, and this pool could have been enhanced continuously with the nitrate regenerated by in situ nitrification (Dham et al. 2002).

Other factors that could have determined species succession are silicon and salinity. Except for the high

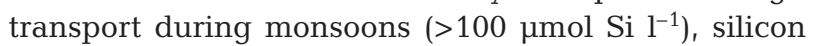
concentrations were nearly uniform throughout the 


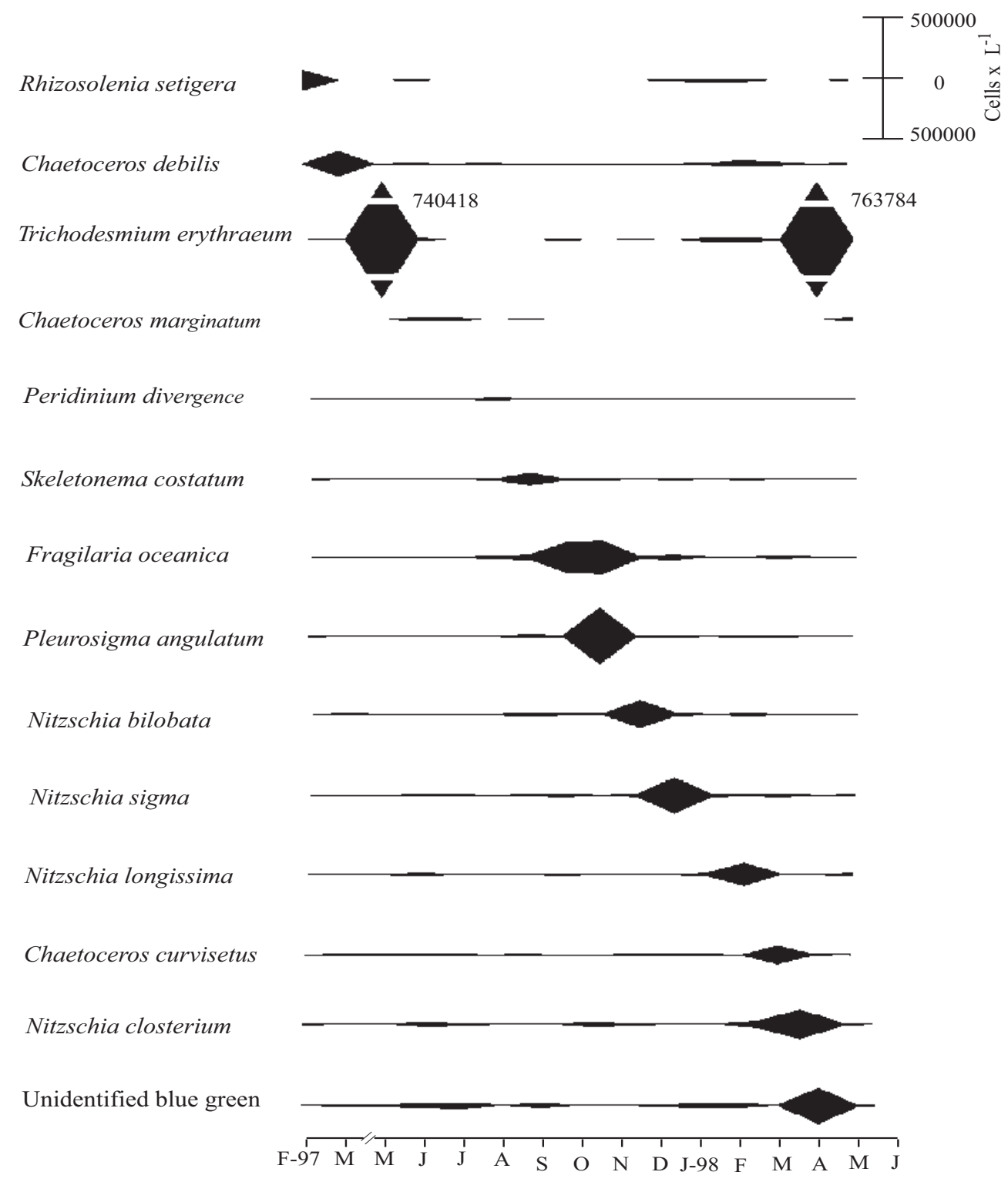

Fig. 10. Succession of phytoplankton species at Stn 2

non-monsoon months, and were never $<6 \mu$ mol Si $\mathrm{l}^{-1}$ (S. Hindlekar pers. comm.). Salinity, therefore, was the likely cause of species succession. Qasim et al. (1972) observed that occurrences of various species of diatoms were related to specific ranges of salinity in the Kochi backwaters on the west coast of India. In a nearby estuarine system with hydrological characteristics similar to those at our study site, Devassy \& Goès (1988) observed a succession of phytoplankton species that they hypothesised to be related to changes of salinity and water transparency. Comparison with their data showed that the abundances of Trichodesmium sp., Skeletonema costatum, Fragilaria oceanica, Pleurosigma angulatum, Nitzschia bilobata, N. sigma, $N$. longissima, N. closterium, Chaetoceros curvisetus and the blue green algae were similar in the same months of both studies. In addition, our data concurred with the dominance of pennate diatoms in the postmonsoon and of centrics in the pre-monsoon periods observed by Devassy \& Goès (1988).

In conclusion, our data provide support for the generally accepted association between phytoplankton size classes and type of $\mathrm{N}$ nutrient (nitrate or ammonium) used. However, such relationships are also regulated by interactions between nitrate and ammonium as $\mathrm{N}$ sources, as well as by water temperature. While phytoplankton groups on the whole may have a preference for a particular $\mathrm{N}$ nutrient, their species composition or succession could be determined by factors other than the $\mathrm{N}$ uptake pattern, for example salinity. 
Acknowledgements. We thank 3 anonymous reviewers for their constructive comments on the manuscript. Financial assistance for this work was provided by a grant from the Office of Naval Research, USA. This is Contribution No. 4037 from the National Institute of Oceanography, Goa.

\section{LITERATURE CITED}

Berg GM, Balode M, Purina I, Bekere S, Bechemin C, Maestrini SY (2003) Phytoplankton community in relation to availability and oxidized and reduced nitrogen. Aquat Microb Ecol 30:207-219

Bode A, Dortch Q (1996) Uptake and regeneration of inorganic nitrogen in coastal waters influenced by the Mississippi River: spatial and seasonal variations. J Plankton Res 18:2251-2268

Chang FH, Vincent WF, Woods PH (1989) Nitrogen assimilation by three size fractions of the winter phytoplankton off Westland, New Zealand. NZ J Mar Freshw Res 23: 491-505

Chang FH, Vincent WF, Woods PH (1992) Nitrogen utilisation by size-fractionated phytoplankton assemblages associated with an upwelling event off Westland, New Zealand. NZ J Mar Freshw Res 26:287-301

Chisholm SW (1992) Phytoplankton size. In: Falkowski PG, Woodhead AD (eds) Primary productivity and biogeochemical cycles in the sea. Plenum, New York, p 213-237

Dauchez S, Legendre L, Fortier L, Levasseur M (1996) Nitrate uptake by size-fractionated phytoplankton on the Scotian Shelf (Northwest Atlantic): spatial and temporal variability. J Plankton Res 18:577-595

Devassy VP, Goes JI (1988) Phytoplankton community structure and succession in a tropical estuarine complex (central west coast of India). Estuar Coast Shelf Sci 27:671-685

Dham VV, Heredia AM, Wafar S, Wafar M (2002) Seasonal variation in uptake and in situ regeneration of nitrogen in mangrove waters. Limnol Oceanogr 47:241-254

Doering PH, Oviatt CA, Beatty LL, Banzon VF, Rice R, Kelly SP, Sullivan BK, Frithsen JB (1989) Structure and function in a model coastal ecosystem: silicon, the benthos and eutrophication. Mar Ecol Prog Ser 52:287-299

Dortch Q (1990) The interaction between ammonium and nitrate uptake in phytoplankton. Mar Ecol Prog Ser 61: 183-201

Dugdale RC, Goering JJ (1967) Uptake of new and regenerated forms of nitrogen in primary productivity. Limnol Oceanogr 12:196-206

Eppley RW, Peterson PJ (1979) Particulate organic matter flux and planktonic new production in the deep ocean. Nature 282:677-680

Ferguson RL, Rublee P (1976) Contribution of bacteria to standing crop of coastal plankton. Limnol Oceanogr 21: $141-144$

Flynn KJ (1999) Nitrate transport and ammonium-nitrate interactions at high nitrate concentrations and low temperature. Mar Ecol Prog Ser 187:283-287

Flynn KJ, Fasham MJR, Hipkin CR (1997) Modelling the interactions between ammonium and nitrate uptake in marine phytoplankton. Phil Trans R Soc Lond B 352: $1625-1645$

Furnas MJ (1983) Nitrogen dynamics in lower Narragansett Bay, Rhode Island. 1. Uptake by size-fractionated phytoplankton populations. J Plankton Res 5:657-676

Glibert PM, Goldman JC, Carpenter EJ (1982) Seasonal variations in the utilization of ammonium and nitrate by phytoplankton in Vineyard Sound, Massachusetts, USA.
Mar Biol 70:237-249

Harrison WG, Wood LJE (1988) Inorganic nitrogen uptake by marine picoplankton: evidence for size partitioning. Limnol Oceanogr 33:468-475

Kokkinakis SA, Wheeler PA (1988) Uptake of ammonium and urea in the northeast Pacific: comparison between netplankton and nanoplankton. Mar Ecol Prog Ser 43: 113-124

Legendre L, LéFevre J (1991) From individual plankton cells to pelagic marine ecosystems and to global biogeochemical cycles. In: Demers S (ed) Particle analysis in oceanography. Springer, Heidelberg, p 261-300

Lomas MW, Glibert PM (1999) Temperature regulation of nitrate uptake: a novel hypothesis about nitrate uptake and reduction in cool-water diatoms. Limnol Oceanogr 44:556-572

Maguer JF, Wafar M, Madec C, Morin P, Erard-Le Denn E (2004) Nitrogen and phosphorus requirements of an Alexandrium minutum bloom in the Penzé estuary, France. Limnol Oceanogr 49:1108-1114

Malone TC (1980) Algal size. In: Morris I (ed) The physiological ecology of phytoplankton. University of California Press, Berkeley, CA, p 433-463

Mulholland MR, Shoemaker C, Ohki K, Capone DG (1999) Utilization of combined forms of $\mathrm{N}$ in cultured and natural populations of Trichodesmium spp. In: Charpy $\mathrm{L}_{\text {, }}$ Larkum AWD (eds) Marine Cyanobacteria. Musée océanographique NS19, Monaco, p 279-285

Pasciak WJ, Gavis J (1974) Transport limitation of nutrient uptake in phytoplankton. Limnol Oceanogr 19:881-888

Probyn TA (1985) Nitrogen uptake by size-fractionated phytoplankton populations in the southern Benguela upwelling system. Mar Ecol Prog Ser 22:249-258

Probyn TA, Painting SJ (1985) Nitrogen uptake by sizefractionated phytoplankton population in Antarctic surface waters. Limnol Oceanogr 30:1327-1331

Qasim SZ, Bhattathiri PMA, Devassy VP (1972) Influence of salinity on the rate of photosynthesis and abundance of some tropical phytoplankton. Mar Biol 12:200-206

Riegman R, Noordeloos AAM (1998) Size-fractionated uptake of nitrogenous nutrients and carbon by phytoplankton in the North Sea during summer 1994. Mar Ecol Prog Ser 173:95-106

Riegman R, Flameling IA, Noordeloos AAM (1998) Sizefractionated uptake of ammonium, nitrate and urea and phytoplankton growth in the North Sea during spring 1994. Mar Ecol Prog Ser 173:85-94

Stal LJ, Walsby AE (1998) The daily integral of nitrogen fixation by planktonic cyanobacteria in the Baltic Sea. New Phytol 139:665-671

Stolte W, McCollin T, Noordeloos AAM, Riegman R (1994) Effect of nitrogen source on the size distribution within marine phytoplankton populations. J Exp Mar Biol Ecol 184:83-97

Strickland JDH, Parsons TR (1972) A practical handbook of seawater analysis. J Fish Res Board Can 167:310

Wafar M, L'Helguen S, Raikar V, Maguer JFM, Le Corre P (2004) Nitrogen uptake by size-fractionated plankton in permanently well-mixed temperate coastal waters. J Plankton Res 26:982-993

Wheeler PA, Kokkinakis SA (1990) Ammonium recycling limits nitrate use in the oceans. Limnol Oceanogr 30: $1267-1278$

Wilkerson FP, Dugdale RC, Kudala RM, Chavez FP (2000) Biomass and productivity in Monterey Bay, California: contribution of the large phytoplankton. Deep-Sea Res Part B 47:1003-1022 